\title{
Meðhöndlun sykursýki af tegund 1 hjá fullorðnum - er búið að leysa málið?
}

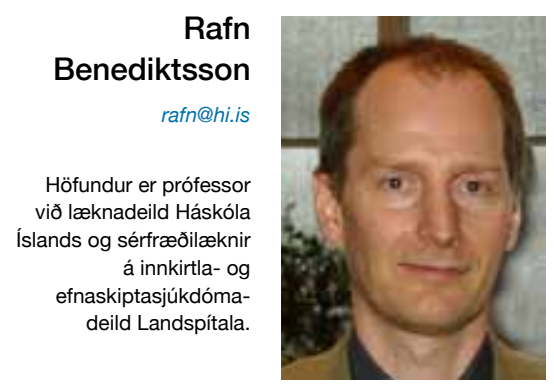

MIKIĐ VATN hefur runnið til sjávar á peim tæpu 100 árum frá pví insúlín var fyrst notað til meðhöndlunar á sykursýki af tegund 1. Раð var bylting sem gjörbreytti horfum sjúklinganna og sjúkdómurinn varð ekki lengur öruggur vísir að bráđum bana. Nákvæmar aðferðir parf til gjafar á insúlíni og ekki síður til mælinga á blóðsykurgildum ef takast á að líkja eftir eðlilegri starfsemi líkamans. Petta er erfitt og pví hafa langvinnir (síðkomnir) fylgikvillar verið algengt og erfitt vandamál. Og pó fljótlega hafi orðið framfarir á sviði efnafræði og erfðatækni sem að lokum skilaði manna-insúlín-hliðstæðum (human insulin analogues), er pað fyrst á síðustu árum sem verulegar framfarir hafa orðið á pví hvernig insúlíni er komið í líkamann og blóðsykur mældur.

Venjuleg nútímameðferð snýst um að nota tvær tegundir insúlín-hliðstæðu í einnota penna, oft 5-10 aðskildar inndælingar insúlíns með að minnsta kosti jafnmörgum mælingum á blóðsykri. Fyrsta insúlíndælan kom fram árið 1963 en pað var ekki fyrr en uppúr 1980 að framfarir í verkfræði og tölvutækni gátu af sér smækkun íhluta og fullkomnari reiknilíkön pannig að hálfsjálfvirkar dælur eru nú raunverulegur valkostur. Pessar dælur nota eingöngu hraðvirkt insúlín sem dreypt er undir húð í breytilegu magni eftir stillingu notandans. Tæknilegar framfarir hafa auðvitað einnig orðið á sviði blóðsykurmælinga og nú er mögulegt að mæla sykurgildið með sjálfvirkum hætti í millifrumuvökva á fimm mínútna fresti og safna sjálfkrafa í dæluna. Dælan getur pá stutt notandann við ákvörðun á skömmtum eða varað við hröðum og miklum breytingum á blóðsykurgildum. Petta er stórkostleg tækni og sú spurning vaknar óhjákvæmilega hvort petta sé besta mögulega meðferðin og hin endanlega lausn.

Erlendar kannanir benda til pess að flestir sem reyna dælu kjósi að nota pær áfram og lífsgæði peirra virðast almennt aukast. Nýleg slembiröðuð meðferðartilraun bar saman nútímapennameðferð og dælu sem var tengd sjálfvirkum mæli. ${ }^{1}$ Pessi rannsókn sýndi marktækt betri blóðsykurstjórn tilraunahópsins með lækkun á HbA1c uppá 0,6\% umfram viðmið. Petta er samhljóða samantekt ${ }^{2}$ á eldri stýrðum meðferðarrannsóknum en ekki samhljóða nýrri úttekt ${ }^{3}$ á slembuðum stýrðum meðferðarrannsóknum sem benti til pess að sykurstjórn batnaði ekki nema hún væri nokkuð slök fyrir (HbA1c >8,5\%). ${ }^{2}$ Munurinn kann að stafa af pví að í nýrri samantektinni var samanburðurinn við sjúklinga sem notuðu insúlín-hliðstæður fremur en eldri tegundir insúlíns. Раð kemur ekki á óvart að mjög sterkt jákvætt samband virðist á milli raunverulegrar notkunar einstaklings á tækninni og árangri viðkomandi $^{1}$ en reynsla lækna bendir reyndar til pess að pessari kröfu um aukna sjálfsumönnun sé ekki ætíð svarað og gildir pað einnig um hefðbundna meðferð. Ætla mætti að sykurföllum fækkaði með notkun pessarar fullkomnu tækni en svo virðist ekki vera ${ }^{1,3}$ né virðast til góð gögn sem styðja notkun pessarar tækni fyrir barnshafandi konur. ${ }^{3}$

Í pessu tölublaði Læknablaðsins er greint frá árangri fullorðinna dælunotenda á göngudeild Landspítala. ${ }^{4}$ Í heild varð ekki marktækur bati á $\mathrm{HbA1c}$ og sé litið á gögn einstakra pátttakenda er hugsanlegt að nokkrir hafi versnað á tímabilinu. Petta er áhyggjuefni en fram kemur að markmiðið hafi í upphafi fyrst og fremst verið að afla reynslu. Upphafsgildi $\mathrm{HbA1c}$ voru einnig talsvert lægri en í flestum erlendum rannsóknum sem hafa sýnt ávinning við sykurstjórn sjúklinga. Pessi rannsókn mat ekki lífsgæði með formlegum hætti en eins og erlendis kaus fólk ekki að skipta aftur yfir í hefðbundna meðferð eftir að hafa reynt dælu. Ekki var metið hvort tíðni sykurfalla eða ketónblóðsýringar var önnur en búast mætti við hjá pessum íslenska hópi.

Pessi tækni er dýr og pað sem íslensk heilbrigðisyfirvöld og við læknar verðum að spyrja okkur að á pessari stundu er pað hvort tæknin sé kostnaðarins virði. Nær allir sjúklingarnir munu segja já og allmargir erlendir fagaðilar virðast telja að svo sé. Раð er hins vegar ekki öruggt að hægt sé að yfirfæra niðurstöður erlends kostnaðarmats yfir á kerfið hér heima. Рað hlýtur pví að vera krafa að hér á landi fari fram formlegt lífsgæða- og kostnaðarmat. раð er mikilvægt að tekin sé afstaða til pess hvað lífsgæði megi kosta hér eins og gert hefur verið erlendis. Sömuleiðis parf að leita allra leiða til að minnka kostnað, svo sem með pví að búa til samkeppnismarkað og viðhafa útboð. Við læknar purfum einnig að gæta pess að fylgja ströngum ábendingum um val til pessarar meðferðar og gera reglulega mat á árangri - pað parf formlegar klínískar leiðbeiningar. Fjöldi og aðbúnaður heilbrigðisstarfsfólks parf að vera með peim hætti að hægt sé að veita pá gagneyndu pjónustu sem parf til að ná settum markmiðum í meðferð sykursjúkra.

\section{Heimildir}

1. Bergenstal RM, Tamborlane WV, Ahmann A, et al Effectiveness of sensor-augmented insulin-pump therapy in type 1 diabetes. N Engl J Med 2010; 363: 311-20.

2. Pickup J, Mattock M, Kerry S.Glycaemic control with continuous subcutaneous insulin infusion compared with intensive insulin injections in patients with type 1 diabetes: meta-analysis of randomised controlled trials. BMJ 2002; 324: 705.

3. NICE technology appraisal guidance 151, continous subcutaneous insulin infusion for the treatment og diabetes mellitus. quidance.nice.org.uk/TA151 apríl 2011.

4. Böðvarsdóttir KÓ, Aspelund T, Guðmundsdóttir A. Meðferð sykursýki af tegund 1 með insúlíndælu hjá fullorðnum á Íslandi. Læknablaðið 2011; 97: 291-5.

Treatment of type 1 diabetes in adults - problem solved?

Professor of Medicine, University of Iceland and Consultant Physician, Department of Endocrinology and Metabolism, Landspitali University Hospital. 